University of New Hampshire

University of New Hampshire Scholars' Repository

$1-9-2012$

\title{
Nonprofit governance: Improving performance in troubled economic times
}

Jerry D. Marx

University of New Hampshire, Jerry.Marx@unh.edu

Christie Davis

University of New Hampshire

Follow this and additional works at: https://scholars.unh.edu/socwork_facpub

Part of the Social Work Commons

\section{Recommended Citation}

Marx, J.D. \& Davis, C. (2012) Nonprofit governance: Improving performance in troubled economic times. Administration in Social Work, 36 (1), 40-52.

This Article is brought to you for free and open access by the Social Work at University of New Hampshire Scholars' Repository. It has been accepted for inclusion in Social Work Scholarship by an authorized administrator of University of New Hampshire Scholars' Repository. For more information, please contact Scholarly.Communication@unh.edu. 
This article was downloaded by: [University of New Hampshire]

On: 24 August 2012, At: 08:41

Publisher: Routledge

Informa Ltd Registered in England and Wales Registered Number: 1072954 Registered

office: Mortimer House, 37-41 Mortimer Street, London W1T 3J H, UK

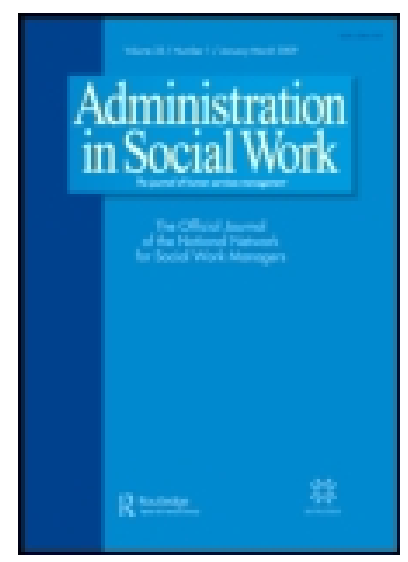

\title{
Administration in Social Work
}

Publication details, including instructions for authors and subscription information:

http:// www. tandfonline.com/loi/ wasw20

\section{Nonprofit Governance: Improving Performance in Troubled Economic Times}

\author{
Jerry Marx ${ }^{a} \&$ Christie Davis ${ }^{b}$ \\ a Department of Social Work, University of New Hampshire, Durham, \\ New Hampshire, USA \\ ${ }^{b}$ Center for Professional Excellence in Child Welfare, University of \\ New Hampshire, Durham, New Hampshire, USA
}

Accepted author version posted online: 01 Nov 2011. Version of record first published: 09 J an 2012

To cite this article: J erry Marx \& Christie Davis (2012): Nonprofit Governance: Improving Performance in Troubled Economic Times, Administration in Social Work, 36:1, 40-52

To link to this article: http:// dx.doi.org/ 10.1080/03643107.2010.550670

\section{PLEASE SCROLL DOWN FOR ARTICLE}

Full terms and conditions of use: http://www.tandfonline.com/page/terms-and-conditions

This article may be used for research, teaching, and private study purposes. Any substantial or systematic reproduction, redistribution, reselling, loan, sub-licensing, systematic supply, or distribution in any form to anyone is expressly forbidden.

The publisher does not give any warranty express or implied or make any representation that the contents will be complete or accurate or up to date. The accuracy of any instructions, formulae, and drug doses should be independently verified with primary sources. The publisher shall not be liable for any loss, actions, claims, proceedings, demand, or costs or damages whatsoever or howsoever caused arising directly or indirectly in connection with or arising out of the use of this material. 


\title{
Nonprofit Governance: Improving Performance in Troubled Economic Times
}

\author{
JERRY MARX \\ Department of Social Work, University of New Hampshire, \\ Durham, New Hampshire, USA \\ CHRISTIE DAVIS \\ Center for Professional Excellence in Child Welfare, University of New \\ Hampshire, Durham, New Hampshire, USA
}

\begin{abstract}
Nonprofit management is currently pressured to perform effectively in a weak economy. Yet, nonprofit governance continues to suffer from unclear conceptions of the division of labor between board of directors and executive directors. This online survey of 114 executive directors aims to provide clarification and recommendations for social administration.
\end{abstract}

KEYWORDS governance, leadership, management, nonprofit, social administration

\section{INTRODUCTION}

The year 2010 finds the United States trying to recover from the worst economy since the Great Depression. During recessions, human service nonprofit organizations are typically the first to see an increase in demand for services and a slowing of cash donations. (Center on Philanthropy, 2008) Thus, nonprofit management and leadership are currently under intensified pressure to perform effectively. There is a significant amount of literature today on various aspects of "nonprofit governance," defined here as the management and leadership of private nonprofit organizations. Recent publications focus on governance in general (Schick, 2009; Cheverton, 2007; O'Connell, 2003, Tweeten, 2002), management (Drucker, 2006; Brinckerhoff, 2003,

Address correspondence to Jerry Marx, Department of Social Work, University of New Hampshire, Pettee Hall, Durham, NH 03824, USA. E-mail: jerry.marx@unh.edu 
Linnell, Radosevich, \& Spack, 2002), leadership (Chait et al, 2005; Dym \& Hutson, 2005; Howe, 2003), and fundraising (Panas, 2006; Karsh \& Fox, 2006, Robinson, 2002; Weinstein, 2002, Young, Wyman, \& Swaigen, 2002; Klein \& Roth, 2001, Klein, 2000). Some of this literature addresses the issues and needs of specific groups such as women and minorities (Carter \& Marx, 2007; Newman, 2002; Pettey, 2002, 2001; Conley, 2000; Marx, 2000). Some of it addresses specialized skills such as grant writing and program evaluation (Yuen \& Terao, 2003; Barber, 2002; Smith, McLean \& Coles, 2001).

Yet, according to the literature, the management and leadership of nonprofit agencies continue to present major challenges to those who are active in the field (Hall, 2010; Center on Philanthropy, 2008; Schwinn, 2007; Brown, 2006; Gibelman, 2004; Roth, 2003; Chalkley, 2002). The executive directors of nonprofit agencies continue to deal with disengaged boards, boards that are burnt out and unenthusiastic, feuding board members seeking power and control, and overly compliant boards offering little or no direction to the agency. What is more, some nonprofit boards operate much like social clubs where people gather to see friends and acquaintances, but shy away from the difficult issues involved in running a nonprofit agency. Board meetings continue to be poorly run. Board members generally continue to struggle with raising funds for their agencies and understand little about organizational performance evaluation-even though monitoring and evaluating agency outcomes is commonly viewed as a primary responsibility of boards of directors.

Furthermore, a major source of problems in nonprofit agencies is the conflicting conception of the division of labor between the board of directors and the executive director. Common nonprofit governance roles and responsibilities include establishing and promoting an agency mission; ensuring proper financial, legal, and ethical oversight; conducting periodic strategic planning; ensuring adequate agency resources (including adequate funding); recruiting and orienting new board members; monitoring the effectiveness of agency programming; and assessing board performance. (The board also hires, supports, and evaluates the executive director).

As previously stated, there is ample literature on the topic, but no clear, commonly accepted model of nonprofit governance. Part of this is due to the historical roots of nonprofit agencies and the nonprofit sector in the United States. In the "historical model," the social agency starts out as a voluntary association of like-minded individuals attempting to meet some need and/or promote some cause. These volunteers do the work normally associated with both the board and the staff_-including management. (Board historians often are fond of recalling this period!) As the agency continues to grow and get more complex over time, typically a staff person is hired to support the volunteers in their work. This is when and where nonprofit governance ["management" deleted] gets murky. When staff members are hired, who does what? 
There are several contemporary models that have been offered in theory, if not in practice, to answer this question. In the "hierarchical" model of nonprofit governance (also called the "traditional" model, Carver \& Carver, 1997), the board of directors defines the purpose of the agency in terms of its mission, vision, and values, and sets policy parameters for achieving this purpose. It is then the responsibility of the executive director to execute policy around key functional areas (fundraising, program development, staff development, etc.). Typically in this hierarchical model there is little formal evaluation of organizational outcomes except in the area of finances. Instead, the board maintains accountability for agency performance by monitoring operations and approving staff initiatives. This model tends to be more of a top-down, command-and-control relationship between the board and executive director.

A second model is the "policy governance" model (Carver \& Carver, 1997). In this model, the board establishes and regularly reviews the purpose of the agency in terms of agency mission, vision, and values; it then holds the executive director accountable for achieving organizational outcomes in a legal, ethical, and prudent manner through a rigorous evaluation processes. In other words, the board focuses on "policy governance" and is not directly involved in agency management. It delegates management roles and responsibilities. The executive director is accountable to the board as a whole, but the relationship between the executive director and individual board members is seen as collegial and not hierarchical.

A third model is the "partnership" model (Linnel, Radosevich, \& Spack, 2002). In this model, the board of directors and executive director (and the rest of the staff) collaborate closely on both policy and operational management. There is no role or function for which either board or staff is exclusively responsible. All participate in establishing and reviewing the agency purpose (mission, vision, values). Everyone is held accountable for agency outcomes. The relationship between the board and executive director is seen as a partnership in which each entity shares power by actively participating in policy and administrative tasks. A clear distinction between the roles and responsibilities of the board and executive director is seen as unneeded, even counterproductive, in a complex, rapidly changing environment. All three of these models offer different conceptions of what the relationship between the board of directors and executive director should look like in a nonprofit agency.

Given that there is no clearly and commonly accepted model of nonprofit governance, the social work profession should seek to prepare professionals for competency in what nonprofit leaders and social administrators actually do in the field. In other words, one way to address the board-executive dilemma is to document what nonprofit boards of directors and executive directors normally do in practice ("in the real world"). This was the subject of a survey conducted by the University of New Hampshire in collaboration with the N.H. Center for Nonprofits, the United 
Way of the Greater Seacoast, and the N.H. Department of Justice. The study was designed to provide a current portrait of the ways executive directors and nonprofit board members in New Hampshire carry out their roles and responsibilities.

While there is much prescriptive literature on nonprofit leadership and management (see above), there is relatively little empirical research, especially on the respective roles of nonprofit board and executives. Several authors have conducted empirical studies of other aspects of nonprofit governance (Stoecker, 2007; Wallis \& Dollery, 2005; McCambridge, 2004; Callen, Klein, \& Tinkelman, 2003; Marx, 2000). Of the empirical research that has been published recently on the relationship between the nonprofit board and executive director, some studies have been limited by small sample sizes (Iecovich \& Bar-Mor, 2007; Gibelman, 2004) and others, for our purposes, by unclear conclusions regarding the precise roles of boards and executives (Iecovich, 2005; Nobbie \& Brudney, 2003). The organization, BoardSource, periodically does a national survey of nonprofit board members and executives, a survey that asks respondents to assess their nonprofit board's performance, composition, policies, and practices. The latest survey (2007) found that nonprofit board members "do not understand their roles very well" (p. 13).

The objective of the current study was to build upon the survey work of BoardSource to explore and clarify the respective roles and responsibilities of nonprofit boards and executive directors from the perspective of executive directors currently in practice. The methods by which the authors pursued this objective are detailed as follows.

\section{METHODOLOGY}

A self-administered questionnaire adapted from that used in the 2007 BoardSource survey was employed to obtain information from nonprofit executive directors in the study. The New Hampshire Center for Nonprofits sent Survey Monkey links for the survey to the executive directors on its e-mail list. The executive directors were asked to voluntarily complete the questionnaire. In addition, the New Hampshire Center for Nonprofits posted the links on its website and in its e-newsletter. Participants completed their respective questionnaire via Survey Monkey, and the data were subsequently transferred to an SPSS dataset for analysis. The questionnaire consisted of six sections: general information, board composition, board development, board structures, board performance, and oversight policies and practices.

During February and March 2009, a total of 114 executive directors completed the online survey representing a wide range of nonprofit fields and disciplines. Given the various distribution methods, it is unclear exactly how many executive directors viewed the invitation to participate in this study. 
Therefore, a response rate could not be calculated. In addition, the generalizability of this electronic survey is limited by a nonprobability sample, potentially unreliable e-mail addresses, possible participant inexperience using Survey Monkey, and typical reluctance to participate in surveys. Study findings are presented below.

\section{SURVEY FINDINGS}

The range of nonprofit fields and disciplines participating in this survey included human services $(31.4 \%, \mathrm{n}=33)$, health $(14.3 \%, \mathrm{n}=15)$, and education $(11.4 \%, \mathrm{n}=12)$. A substantial "other" category, comprising 20\% of responses, reflected still more fields such as civic engagement $(.1 \%, \mathrm{n}=1)$, housing $(.1 \%, \mathrm{n}=1)$, historic preservation $(.2 \%, \mathrm{n}=2)$, and more. These statistics are consistent with a recent New Hampshire study (The New Hampshire Center for Nonprofits, n.d.), which cited 2008 IRS data on the number and types of N.H. nonprofit organizations, suggesting that the sample of nonprofits used here is somewhat representative of New Hampshire's nonprofit sector as a whole.

In addition to varying fields of work, the results indicate that New Hampshire nonprofit budget sizes and years in operation vary greatly. The median budget size as reported by executive directors was $\$ 612,500$, based on a range of $\$ 250$ to $\$ 892$ million. Executive directors indicated that the median number of employees is 9.5 , though $11 \%(n=12)$ reported that their organization only has one employee. Based on a range of 3 years to 137 years as reported by executive directors, the average length of an organization's operation was 34 years. All executive directors reported that their organization has a mission statement, and three quarters have a written strategic plan $(75 \%, n=79)$, while $60 \%(n=64)$ have a vision statement.

The executive directors surveyed reflected a variety of educational backgrounds. Approximately 58\% $(n=61)$ of executive directors reported that they have a graduate/law degree and just under one-third of respondents have a bachelor's degree $(31.4 \%, \mathrm{n}=33)$. The primary fields of education for this sample of executive directors were business administration (23.8\%, $\mathrm{n}=25)$, social work (12.4\%, $\mathrm{n}=13)$, and education $(11.4 \%$, $\mathrm{n}=12$ ). In terms of salary, half of executive directors surveyed indicated that their salary range is $\$ 50,000-\$ 74,999(50 \%, \mathrm{n}=53)$. An additional $21.7 \%$ $(n=23)$ earn $\$ 25,000-\$ 49,999,12.3 \%(n=13)$ earn $\$ 75,000-\$ 99,999$, and $10.4 \%(n=11)$ earn over $\$ 100,000$.

Executive director participants were asked a series of questions regarding the individuals who comprise the board of their respective organizations. Respondents indicated that their board consists of an average of 6.68 men and 6.37 women, of which less than one person (.47) is a racial/ethnic minority. 


\section{Board Development}

As stated earlier, board development (recruitment, orientation, evaluation) is a common nonprofit governance responsibility. The 114 nonprofit executive directors who participated in this survey were asked to rate the level of involvement of agency management and leadership in board recruitment. Responding executive directors felt that they were most involved in this process as compared to other members of the organization. On a scale from "no involvement" to "high involvement," 93\% ( $n=101)$ of executive directors felt they were "moderately" or "highly" involved in board recruitment, while only 86\% ( $n=96)$ experienced the same level of involvement from their board chair, governance/nominating committee $(72 \%, \mathrm{n}=77)$, or other board members $(61 \%, \mathrm{n}=66)$.

Nearly three quarters of executive directors $(72.1 \%, \mathrm{n}=80)$ stated that their organization has a structured, in-person orientation for new board members. In addition, more than one-third $(36.4 \%, \mathrm{n}=40)$ indicated that they "often" (25.5\%, $\mathrm{n}=28)$ or "continually" $(10.9 \%, \mathrm{n}=12)$ attempt to define the board's roles and responsibilities. Yet, nearly two-thirds $(63.6 \%$, $\mathrm{n}=70$ ) of these nonprofits attempt to do this "occasionally" at best. In fact, some "never" do $(2.7 \%, \mathrm{n}=3)$.

Evaluation of board performance appears to be an area in which New Hampshire nonprofit practice also varies. More than half of the executive directors surveyed indicated that evaluations of board performance are conducted $(55 \%, \mathrm{n}=60)$. Nearly a quarter of participants $(24 \% \mathrm{n}=26)$ stated that board performance is evaluated "every 2-3 years." This was the most common time frame for those that do some sort of formal evaluation of board performance. However, almost half of respondents (45\%, $\mathrm{n}=50$ ) stated that they "never" conduct a formal, written evaluation of board performance.

The majority of respondents $(66.1 \%, \mathrm{n}=41)$ indicated that the board as a whole is solely responsible for conducting these evaluations of its performance, while $16.1 \%(n=10)$ stated that the board enlists the help of an outside facilitator to assist them in their self-evaluation.

\section{Board Structures}

In order to gain a better understanding of board structure, executive director survey participants were asked specific questions about the format of board meetings, who is involved in the planning of the meetings, as well as the responsibilities of individual members and sub-committees. The executive directors surveyed indicated that on average 9.26 formal board meetings are held annually, each lasting approximately two hours in length. Respondents stated that at any given board meeting an average of $78.9 \%$ of board members are in attendance. In a series of questions about board meetings 
TABLE 1 Features of Board Meetings

\begin{tabular}{lc}
\hline & $\begin{array}{c}\text { Respondents rating } \\
\text { "Often" or "Always" n (\%) }\end{array}$ \\
\hline $\begin{array}{l}\text { Are materials distributed sufficiently in advance } \\
\text { of board meetings? }\end{array}$ & $96(87 \%)$ \\
Do meetings start and end on time? & $99(90 \%)$ \\
Are discussions kept on track? & $103(94 \%)$ \\
Is there a clear meeting agenda? & $107(97 \%)$ \\
Do all board members express themselves? & $86(79 \%)^{*}$ \\
Is there a positive atmosphere at board & $107(97 \%)$ \\
$\quad$ meetings? & \\
\hline
\end{tabular}

$1=$ Never, 2 = Seldom, $3=$ Occasionally, $4=$ Often, and $5=$ Always.

*Percentages based on $\mathrm{N}=110$, except with this item where $\mathrm{N}=109$.

(see Table 1), executive directors in this study rated their respective board meetings positively in terms of meeting preparation and conduct.

The majority of executive directors stated that they are responsible for setting the board meeting agenda (57.8\%, $\mathrm{n}=63$ ). An additional 12.8\% $(n=14)$ reported that the board president and executive director work jointly to create board meeting agendas, while $17.4 \%(n=19)$ stated that board president is solely responsible for setting the agenda.

Executive directors indicated that the structure of their respective boards includes a variety of sub-committees created for specific tasks and responsibilities. The most common sub-committees include finance (79.2\%), executive (68.9\%), fundraising (67.9\%), and governance/nominating (66\%).

Nearly all executive directors $(99.1 \%, \mathrm{n}=105)$ reported that board members serve on board sub-committees, and over three-quarters of executive directors $(76.4 \%, \mathrm{n}=81)$ stated that they serve on sub-committees themselves. In addition, respondents indicated that staff members (58.5\%, $\mathrm{n}=62)$ and former board members (48.1\%, $\mathrm{n}=51)$ are represented on sub-committees, as well as community members/volunteers (15.1\%, $\mathrm{n}=16)$. An additional 27.4\% $(n=29)$ of participants stated that clients/consumers serve on board sub-committees.

\section{Board Performance}

In order to clarify the roles and responsibilities of board members and executive directors, participants were asked to rate the extent to which the board and/or executive director were involved in a series of governance tasks (on a scale of $1=$ exclusively board to $7=$ exclusively executive director). In other words, these questions sought to assess the extent to which various responsibilities were exclusive to board members, exclusive to the executive director, and those that were shared between the two. The results show (Table 2) that executive directors feel that they are more involved in these 
TABLE 2 At Present, To What Extent Does the Board and/or Executive Director Do the Following

\begin{tabular}{lc}
\hline Tasks $(\mathrm{n}=106)$ & Mean \\
\hline Promote an understanding of organization's mission & 4.81 \\
Promote an understanding of board's roles and responsibilities & 4.39 \\
Ensure proper financial oversight & 4.46 \\
Ensure legal and ethical oversight & 4.63 \\
Conduct fundraising & 5.00 \\
Conduct strategic planning & 4.71 \\
Monitor organizational performance outcomes & 5.21 \\
Recruit and orient new board members & 4.34 \\
\hline
\end{tabular}

Scale: 1 = Exclusively Board, $4=$ Equally Shared, $7=$ Exclusively Executive Director.

specific board tasks than board members, but generally most tasks are close to being equally shared.

Questions specific to fundraising were included to assess the degree to which executive directors feel board members are involved in a variety of fundraising activities. Board members play an active role in fundraising activities with approximately three-quarters making a personal financial contribution to the organization $(74.5 \%, \mathrm{n}=79)$ and/or attending fundraising events $(76.4 \%, \mathrm{n}=81)$. Half of the executive directors $(\mathrm{n}=52)$ surveyed stated that every board member at their respective organization makes a personal financial contribution, while only approximately $7 \%$ of executive directors stated that none of their board members contribute financially.

Based on these fundraising responsibilities, executive directors were also asked to rate the willingness of board members to engage in various fundraising-related tasks (Figure 1). The results show that board members are most willing to attend the agency's fundraising events $(M=3.29)$, but least willing to solicit potential donors by phone $(M=2.13)$.

\section{DISCUSSION}

The results of this survey of more than 100 executive directors of nonprofit agencies in New Hampshire indicates that, despite the frequent problematic relationship between nonprofit boards and executive directors, about two-thirds of nonprofits represented in this survey define their roles and responsibilities only "occasionally." Some, in fact, never do. What is more, close to half (45\%) of nonprofits in the study, according to their executive directors, never conduct a formal, written evaluation of board performance. This infrequency of role/responsibility clarification and self-evaluation by nonprofit boards may contribute to the previously described problems between executive directors and nonprofit boards. In addition, almost 50\% 


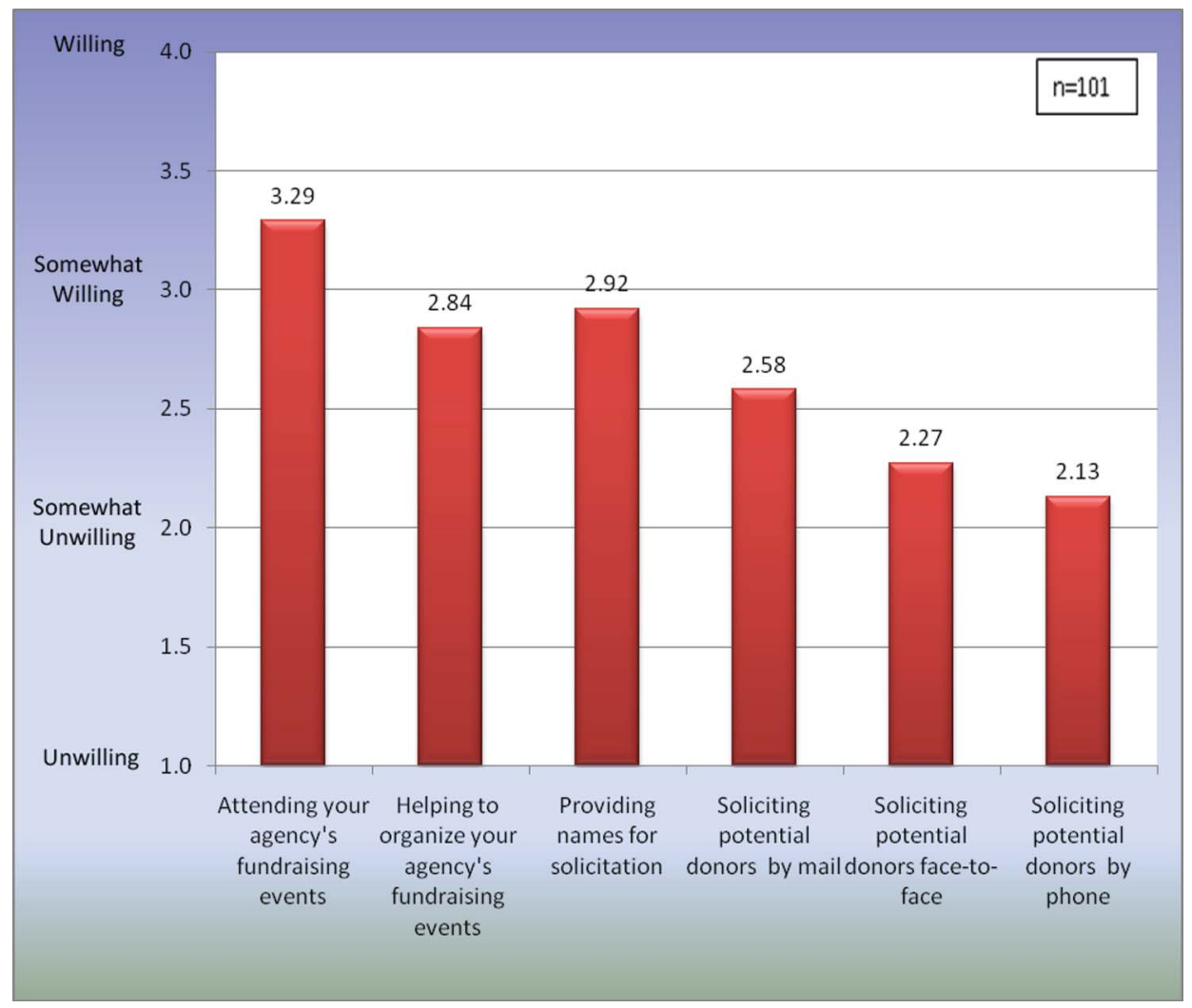

FIGURE 1 How willing are your board members to do each of the following (color figure available online).

of executive directors in this study set the agenda for board meetings entirely by themselves. Thus, it appears that executive directors are relied upon heavily by their boards for direction at least on a month-to-month basis at board meetings. Furthermore, $45.5 \%$ of executive directors in this study state that staff (other than themselves) serve along with board members on board subcommittees. Again the potential for confusion between board and staff roles and responsibilities is evident in this practice.

However, the study's findings suggest that nonprofit organizations in this survey exhibited a shared responsibility on the part of the board and executive director for major governance responsibilities. Therefore, the "New Hampshire way" (a recent state slogan) appears most closely associated with the previously described "partnership" model of nonprofit governance. That is, in New Hampshire, the board and executive director, according to the executives, tended to share responsibilities relatively equally for such tasks as promoting an understanding of the organization's mission and board roles/responsibilities; ensuring proper legal, financial, 
and ethical oversight; conducting strategic planning; and recruiting and orienting new board members. Although fundraising and the monitoring of organizational performance outcomes were also shared, nonprofit boards of directors in this sample tended to rely more on the executive director in carrying out these responsibilities. Board members were particularly uncomfortable soliciting individual donors and tended to rely more on the executive director to complete these tasks.

\section{IMPLICATIONS FOR ADMINISTRATION IN SOCIAL WORK}

The findings and preceding discussion have some very tangible implications for administration in social work. In this survey, the responsibilities for leadership and management in nonprofit agencies appeared to be primarily a shared responsibility between the board of directors and executive director. But "shared" responsibilities can mean no "clear" responsibility leading to miscommunication and poor agency performance. Based upon the findings of this study, it is recommended that yearly reviews be conducted of the way a given nonprofit agency wishes to distribute roles and responsibilities among board members and the executive director. That is, each nonprofit agency needs to clarify on a regular and consistent basis the ways governance is to be shared between the board and chief executive. Such reviews are particularly important in the case where the nonprofit agency has a new board president or new executive director. In addition, such role clarification should be included as part of the orientation and job descriptions for new board members each year. Annual reviews such as these would contribute to and promote clear communication and a consistent understanding of the division of labor among leadership in nonprofit organizations. It would also set the basis for annual evaluations of both the board of directors and the executive director. The result would likely be more frequent self-evaluations by nonprofit boards of directors.

Secondly, this study found that board and staff members commonly serve on board subcommittees. Therefore, it is recommended that the chair of board subcommittees do a yearly review of "board versus staff" roles and responsibilities for their respective committees. The assumption here is that each party brings a specialized expertise or unique perspective to the work of a given subcommittee; otherwise, staff members are not needed on board committees. Without such clarification, subcommittees run the risk of becoming the breeding ground for role confusion between nonprofit boards and executive management.

Third, if fundraising is to truly be a shared responsibility between the board and executive director and not primarily delegated to the executive director (especially in troubled economic times), then board members need training regarding the solicitation of perspective individual donors. 
The results of this survey indicated that board members were especially apprehensive about this responsibility. This finding is consistent with the 2007 BoardSource national survey results that indicated that "fundraising" was second only to "financial sustainability" on the list of board performance items needing improvement according to CEOs surveyed (p. 5). Such board training in donor solicitation should be done during board orientations and periodically afterwards_-for example, as part of annual board retreats. Social work practice methods involving role playing, trust, engagement, goal setting, and collaboration can be applied in such training by administrators and consultants educated in social work.

And, finally, given the relatively heavy responsibility on executive directors for fundraising in this study, social work graduate education should strongly consider requiring its macro/social administration students to take a course in nonprofit organizational development. Such a course should include significant content on fundraising. For example, the final paper in such courses might require students to write a grant for their field placement agency or a local community-based nonprofit organization. Such an assignment would not only require the student to demonstrate a macro competency, but if the grant is eventually funded, might give the social work graduate a competitive advantage in a tight employment market relative to graduating business and public administration students.

\section{REFERENCES}

Barber, D. M., (2002). Finding funding: The comprehensive guide to grant writing. Long Beach, CA: Bond Street Publishers.

BoardSource (2007). Nonprofit governance index 2007. Washington, DC: Author.

Brinckerhoff, P. C. (2003) Mission based marketing: How your non-profit can succeed in a more competitive world. Hoboken, NJ: Wiley.

Brown, J. (2006) The imperfect board member: Discovering the seven disciplines of governance excellence. San Francisco, CA: Jossey-Bass.

Callen, J. L., Klein, A., \& Tinkelman, D. (2003). Board composition, committees, and organizational efficiency: The case of nonprofits. Nonprofit and Voluntary Sector Quarterly, 32(4), 493-520.

Carter, V. B., \& Marx, J. D. (2007). What motivates African-American charitable giving: Findings from a national sample. Administration in Social Work, 31(1), 67-85.

Carver, J., \& Carver, M. M. (1997). The CEO role under policy governance. San Francisco, CA: Jossey-Bass.

Center on Philanthropy at Indiana University (2008), Giving USA 2008: The annual report on philanthropy for the year 2007. New York, NY: Giving USA Foundation.

Chait, R. P., Ryan, W. P., \& Taylor, B. E. (2005). Governance as leadership. Hoboken, NJ: John Wiley \& Sons. 
Chalkley, T. (2002, March 25). Weighing the best strategies for handling problem board members. The Chronicle of Philanthropy. Retrieved from http:// philanthropy.com

Cheverton, J. (2007). Holding our own: Value and performance in nonprofit organizations. Australian Journal of Social Issues, 43(3), 427-436.

Conley, D. (2000) The racial wealth gap: Origins and implications for philanthropy in the African American community. Nonprofit and Voluntary Sector Quarterly 29(4), 530-540.

Dym, B., \& Hutson, H. (2005). Leadership in nonprofit organizations. Thousand Oaks, CA: Sage.

Drucker, P. (2006). Managing the non-profit organization: Principles and practices. New York, NY: Collins.

Gibelman, M. (2004). Reflections on boards and board membership. Administration in Social Work, 28(2), 49-62.

Hall, H. (2010, September 19). Charities brace for challenging giving season. The Chronicle of Philanthropy. Retrieved from http://philanthropy.com.

Howe, F. (2003). The nonprofit leadership team. San Francisco, CA: Jossey-Bass.

Iecovich, E. (2005). Environmental and organizational features and their impact on structural and functional characteristics of boards in nonprofit organizations. Administration in Social Work, 29(3), 43-59.

Iecovich, E., \& Bar-Mor, H. (2007). Relationships between chairpersons and CEOs in nonprofit organizations. Administration in Social Work, 31(4), 21-40.

Karsh, E., \& Fox, A. S. (2006). The only grant-writing book you'll ever need. New York, NY: Carroll \& Graf Publishers.

Klein K. (2000). Fundraising for the long haul. San Francisco, CA: Jossey-Bass.

Klein, K., \& Roth, S. (2001). Raising more money: The best of the grassroots fundraising journal. Oakland, CA: GFJ Publications.

Linnell, D., Radosevich, Z., \& Spack, J. (2002). Executive directors guide: The guide for successful nonprofit management. Boston, MA: Third Sector New England.

Marx, J. D. (2000). Women and human services giving. Social Work, 45(1), $27-38$.

McCambridge, R. (2004). Underestimating the power of nonprofit governance. Nonprofit and Voluntary Sector Quarterly, 33(2), 346-354.

Newman, D. (2002). Opening doors: Pathways to diverse donors. San Francisco, CA: Jossey-Bass.

Nobbie, P. D., \& Brudney, J. L. (2003). Testing the implementation, Board performance, and organizational effectiveness of the policy governance model in nonprofit boards of directors. Nonprofit and Voluntary Sector Quarterly, 32(4), 571-595.

O'Connell, B. (2003). The board member's book: Making a difference in voluntary organizations. New York, NY: The Foundation Center.

Panas, J. (2006). The fundraising habits of supremely successful boards: A 59-minute guide to assuring your organization's future. Medfield, MA: Emerson \& Church.

Pettey, J. G. (2001). Cultivating diversity in fundraising. New York, NY: Wiley.

Pettey, J. G. (2002). Diversity in the fundraising profession: New directions for philanthropic fundraising. San Francisco, CA: Jossey-Bass. 
Robinson, A. (2002). Selling social change (without selling out): Earned income strategies for nonprofits. San Francisco, CA: Jossey-Bass.

Roth, K. (2003, July 17). Advice for keeping board members motivated over the long haul. The Chronicle of Philanthropy. Retrieved from http://philanthropy.com.

Schick, J. D. (2009). The nonprofit secret: Six principles of successful Board/CEO partnerships. Dallas, TX: P3 Press.

Schwinn, E. (2007, November 8). Trustees don't do enough to help charities raise money, study finds. The Chronicle of Philanthropy. Retrieved from http:// philanthropy.com.

Smith, H. S., McLean, D., Coles, R. C. (2001). Grantsmanship \& fundraising fundamentals: Guidelines for human and leisure services professionals. Reston, VA: American Association for Leisure and Recreation.

Stoecker, R. (2007). The research practices and needs of non-profit organizations in an urban center. Nonprofit and Voluntary Sector Quarterly, 34(4), 97-119.

The New Hampshire Center for Nonprofits (n.d.). Essential: A portrait of the nonprofit sector in New Hampshire. Concord, NH: Author.

Tweeten, B. L. (2002). Transformational boards: A practical guide to engaging your board and embracing change. San Fransisco, CA: Jossey-Bass.

Young, J., Wyman, K., \& Swaigen, J. (2002). Fundraising for non-profit groups. Bellingham, WA: Self-Counsel Press.

Yuen, F. K., \& Terao, K. L. (2003). Practical grant writing \& program evaluation. Pacific Grove, CA: Brooks/Cole-Thompson Learning.

Wallis, J., \& Dollery, B. (2005). Leadership and economic theories of nonprofit organizations. Review of Policy Research, 22(4), 483-499.

Weinstein, S. (2002). The complete guide to fundraising management: Second edition. New York, NY: John Wiley \& Sons. 